\title{
The other; multidimensionality as a cultural phenomenon in an artistic context $^{*}$
}

\author{
Barış Güner ${ }^{1}$ \\ Rıfat Şahiner ${ }^{2}$ \\ 1 Dr., FMV Işsk Üniversitesi, Sosyal Bilimler Enstitüsü, Sanat Bilimi Bölümü, İstanbul, TÜRKIYY E-mail: baris.guner@isik.edu.tr \\ 2 Prof. Dr., Yıldız Teknik Üniversitesi Sanat ve Tasarım Fakültesi, Sanat Bölümü, İstanbul, TÜRKIYYE E-mail: rsahiner@yildiz.edu.tr
}

\begin{abstract}
The effects of globalization continue to manifest themselves under present conditions. By this nature, especially the formation of the Other ${ }^{* *}$ within the artistic context of the globalized world calls for the careful consideration of questions and judgments directed towards globalization. In this regard, the aim of this study is defined as exhibiting the ongoing political approaches towards the global systems of art and thereby discussing the geographical and identity-oriented tendencies of this predominant political attitude that is seen as internationalization. The extent of the matter on the Other in this study has been restricted to displaying the relationship between globalization and the systems of art and how the increasingly prevalent practices are shaped. As a result of all these studies, it is found that the notion of the Other is a reflection of a hierarchical relationship and this reflection, along with the geographical and cultural implications of this matter, justifies the argument.
\end{abstract}

Keywords: The Other, ${ }^{* *}$ Art Politics, Representation in Art, Globalization

* This article is generated from the first author's doctoral thesis.

** Because of the particular use of the term, it is preferable to use the other as the Other. 


\section{INTRODUCTION}

The extent of the matter on the Other in this study has been be restricted to displaying the relationship between globalization and the systems of art and how the increasingly prevalent practices are shaped. The discourse around the meaning and origins of the Other brings forth the fact that in Latin, which many European languages have descended from, the word alius (alia and aliud) is used to describe the Other. On another note, as stated in the work of Nahya, the most remarkable aspect of this word is that it is the root of the English word alien. Ceterus, meaning the rest, is also used for Other in Latin. Another word for Other that is used to indicate those who aren't Roman or Hellenic is Barbaria, which has maintained the legacy of Otherness until this day. Therefore, in respect to these cultures that have deeply influenced Europe, the Other concurrently embodies sharp distinctions within itself (Nahya, 2011: 29).

The presentation of these distinctions through various approaches is essential to the versatility of the subject and the trajectory of this study. First, the view on the self in the context of otherness has been evaluated through Foucault's remarks. And later, the matter of the other being a reflection of a hierarchical relationship has been elaborated. As a result of this hierarchical relationship, the study has been shed light on the notion of Orientalism through a comparison of East and West; and through the awareness of the Other, the diverse social behaviours that rise from certain cultural phenomena has been deliberated. In line with these behaviours, after addressing Hegel's master-slave dialectic, the assessment on the notion has been expanded and supported through artworks and different point of views. Additionally, with the global systems of art, the centre and periphery relationship has been presented. Within the framework of the notion of the Other, the focal point of this study will be the response to the question of under which perceptions of reality the paradigms that argue the concept of centrality to be the centre or peripheries to remain out of the centre is assessed. As the final stage, the modes in which artists gain presence in the global market will be focused on through an emphasis on the representation of the Other in globalization and art.

\section{THE DISCUSSION OF THE OTHER}

The formation of the Other can be based on many different views, rather than on a purely existential perspective. Therefore, it is possible to scrutinise the
Other from several perspectives. From Kant to Freud or from Lacan to Foucault, many thinkers have dealt with the term so far, and some of these significant names and their approaches are considered in this article. In this point according to the dialectic and diachronic context it can serve of being a preparation for the theoretical ground of the discussion.

When the view on the self within the context of otherness is evaluated through Foucault's reading, the question of how Rimbaud's otherness evolved into Foucault's otherness has a certain significance. This question takes us to the remark Foucault made in his book The Order of Things and renders it possible to principally emphasize that rather than the Other, the view on the self is foregrounded. In this regard, it appears that in order to define the view on the self, Foucault takes the modern thought into account and defines it as being "imbued with the necessity of...ending man's alienation by reconciling him with his own essence... [and] lifting the veil of unconscious" (Foucault, 2002: 356). This reconciliation with one's own essence implies that in addition to the self, the existentialist counterpart of this self is also reconciled with. Therefore, it can be argued that modern philosophy, rather than alienating the Other, demonstrates an attitude that approves of its potency and Rimbaud's concept of otherness evolves into Foucault's. Sofuoğlu emphasizes that what is put forth with this notion is the assumption that if this self-realization is not inhibited by social obstacles (capitalist conditions), the Self has been develop naturally and the Self (the working class) have the potential to determine its own fate (Aytekin and Tokdil, 2016: 21).

Among those that effectively express their thoughts on the notion of the Other is Héléne Cixous. Cixous questions what the Other is. However, while Cixous underlines that historically, what is referred as the Other is a notion that has fallen into the dialectic circles and can easily be institutionalized, she also indicates that the historical notion of the Other is a reflection of a hierarchical relationship (Nahya, 2011: 70).

Undoubtedly, in the discussion of the Other, the first thing that comes to mind is to make a comparison of East and West in respect of geographical conditions. In this regard, it is of course another point of discourse from whose perspective the East or the West can be designated. For this reason, it might be constructive to emphasise that the context of the situation here is from a European perspective. In order to better understand this distinction, if the notion of the Other is expanded 
to elaborate on the awareness of the Other, it can be stressed that the awareness of the Other is the outcome of various social behaviours caused by cultural phenomena.

The expression of the Other is used to describe the individuals or groups that are of different cultures. The group that has developed a different culture and lifestyle is considered to be different, an Other. The more developed a culture is, the stronger and deeper is the awareness of Difference, Self, and the Other. Orientalism, that gains presence in the form of a political expression of the Eastern identity and otherness, has been imprisoned the East within the bounds of a fictional framework and resurfaced its relationship with the Other that runs parallel to the perceptions within this fictional framework. The segregation constituted voluntarily by the West has been disguised under the mask of Orientalism and non-Western societies are regarded as the Other. In doing so, the imperialism that the West pursues to apply on the East has attempted to be legitimized (Dikici, 2014).

Furthermore, it is to underline that, Chambers emphasizes Said's idea of fate in the post-colonialist era, that is pronounced to be pluralist, as well as collective. Through this emphasis, Chambers states that the pure and unharmed notion of the Other, either on an individual or cultural basis, is among the indispensable elements of the anti-capitalist criticism and judgment oriented towards the Western cultural economy in the modern world (Chambers, 1994: 116). Undoubtedly, when it comes to collectivity, it is inevitable that the process of going from $I$ to $U s$ and from Other to Others is related to the in-groups and out-groups that the individuals integrate themselves into. As an example, Beck indicates this coherence as a collective image of humanity where each individual adheres to their own cultural ground (Beck, 2002: 36). And an individual's relationship with the in-group and out-group they involve themselves in is correlated with that individual's ability to get themselves acknowledged, or recognized. In order for one to get recognized by another, the existence of both sides is undeniably a necessity. In this sense, while one side takes on the role of the one that recognizes, the other plays the part of being recognized. The description of this perceivably natural process corresponds to a synthesis that first, irremissibly transforms a dialectical bias or a reality into its period and later, bears both simultaneously within itself.
One of the main effects of the Hegelian dialectical thinking can be described through the remarks made by Jürgen Habermas, who himself has established the positive integrity of an absolute meaning through a divisive disagreement with the Other. According to Habermas, "Hegel unveils the Modernity discourse: after placing itself as the legitimate centre, it has attributed the Other to a dichotomy" (Feyiz, 2016).

At this exact moment, it is proper to mention the importance of the relationship constituted with the Other as a means for self-consciousness and selfemancipation.

"According to Hegel, the desire for self-consciousness, at this phase of the interconscious relationship, can result in nothing but a war. Therefore, to summarize, the birth of self-consciousness will be inevitably through an interaction with the other self-consciousnesses, and the first form of this relationship will be, again inevitably, the war. Hegel's famous master-slave dialectic is exactly the dialectic of this war and its consequences." (Bumin, 1998:65)

Therefore, in this context, it isn't wrong to suggest that only through recognition by another, a person can reach its own self-consciousness; likewise, selfconsciousness can not only exist for itself but also for another self-consciousness (Henry, 2017, s.5).

In another respect, in their book Empire, Hardt and Negri mention the approaches of Frantz Fanon, while expressing that "master can only achieve a hollow form of recognition; it is the Slave, through life-anddeath struggle, who has the potential to move forward toward full consciousness," they suggest that "the European Self needs violence and needs to confront its Other to feel and maintain its power, to remake itself continually" (Hardt and Negri, 2015: 129). These arguments presented by Hardt and Negri are of supporting nature to the approach that this study has opened up for discussion.

In Hegel's approach, the stigmatization and humiliation that is described to be expressed in the form of prejudice, discrimination, and racism, as well as fueled by stereotypes in one's mind, performs the act of legitimization and externalization of inequality through the practice of essentialism that attempts to explain why individuals are that way through presenting their essence and existence as the ultimate reason. (Uluç and Boz, 2015: 110). There is, however, another approach that is different than 
Hegel's master-slave dialectic. This approach rests in Emmanuel Lévinas's separation of the Self and the Other. In Hegel's context, the slave is obliged to fulfill the desires of the master. Yet, while indulging the master, the slave has to simultaneously educate and improve itself in order to realize its own existence. The slave, on the other hand, is in a perpetual struggle to be removed from this situation and makes the effort to be freed from it. Even though it seems possible for the slave to rise to the status of mastership through these efforts, opposite to Hegel, in Lévinas, there is no such conflict between the Self and the Other; on the contrary, the Self can only reach its own self through the Other (Kader, 2015: 77-91).

On one level, the equalizing and anonymizing effects of the government's legal order revokes the privileges of the Other but on the ethical level, the Other's privileges continue to exist. According to Türk, this view is a breaking point in the Lévinasian approach. Undoubtedly, this approach enables all citizens to move from the domain of state and society, in the context of ethic and law relationships, to the political domain framed within the notion of Otherness:

“When Lévinas's comments on the practical political order are shaped under a perception of threat for the European civilization, the 'dangerous thing to say publicly' seems to be disappearing. Because Lévinas refers to the non-Western cultures as 'countless hordes' who are 'strangers to the weight of its past' and finds the Asians, who he refers to as 'the yellow peril', as unfamiliar and strange as 'a lunar or Martian past'. To suggest that Lévinas prefers the European centralism in line with his quite racist remarks would be to reflect the criticism of a good deal of thinkers." (Türk, 2013: 94).

In this sense, the unity's decision for a distinction between the friend and the enemy and the possibility for this enmity to result in war or killing the other is intrinsic to the political entity. And Lévinas's ethics theory begins with rejecting the approaches and attitudes that take "existence" as the basis on all theoretical-factual levels. Lévinas targets exactly what Schmitt considers as data, the right to self-defense, and aims to substitute this right with the prominence of the Other's existence.
Schmitt's nomos, as the primitive and territorial relationship, is principally the process of a community making its presence visible through the act of "confiscation" of space. The opposite of this state of possessing can be found in Lévinas's description of the ethical relationship that is constructed with the act of giving rather than confiscating and which Lévinas alludes its subject to its passive existence. In Schmitt, the ultimate result of the political relationship is killing the Other; in Lévinas's ethics, however, to not kill is the inherent imperative of the relationship formed with the Other. At this point, what is striking is that Lévinas interprets politics in the way that it is defined in Schmitt-that of pertaining the extremities of the practice of war and killing.

The subject of self, being the opposite end of the right to self-defence, is characterized to have the radical qualities of sacrificing the self for the Other, apologizing for its existence, being hostage to the Other, or doing penance. This radicalism, defined as being completely free in deciding whether the existence of the other means the denial of the self's own right for existence, is also the requirement for constructing an ethical subject that is the exact opposite of the political subject, which is capable of seeing the stranger as the other and as an entity that needs to be destroyed or fought in order to defend its own existence. In other words, the absolute dependence of the Lévinasian ethics on the Other serves the purpose of pointing at the opposite of the qualities imputed on the political subject. In that case, we find the radical representation of the ontological political image that Lévinas attempts to overthrow in Schmitt. When considered this way, Lévinas's theory can be evaluated as an ethical understanding that subsumes the opposite of a political relationship in the way that Schmitt describes.

As Apaydin also touches upon in his work titled Subjectivity and Problem of the Other in Lévinas Philosophy, if we are to mention the approaches regarding Derrida's concept of Otherness through a phenomenological point of view, we can state that Derrida finds the criticism on Husserl's consideration of the Other as the other-self, which is first raised by Lévinas, to be unjust:

"Derrida remarks that the Other, which is separated and differentiated from the Self to the greatest extent 
by Lévinas, needs to be brought to the point where an interaction is possible. According to Derrida, Husserl defines the Other as neither an absolute dissimilitude, nor identical to the Self. The other-self is similar to the Self to the extent which it can form a relationship with it. As the Other is an other-self in comparison to self, the self is also an other-Self to the Other." (Apaydın, 2006: 126).

In another respect, it can be suggested that the intuitional reflection that there is a close link between collective politics and certain opinions about identity and subjectivity is a well-known fact. The studies of Frankfurt School attempted to explain that the Fascism in Europe is a result of a mixture of Marxist and psychoanalytical theory. Thus, the fact that an individual is unable to acknowledge the otherness within oneself on a psychological level reveals itself through the desire to separate the other from inside and pass it onto a figure that is outside of oneself (Benhabib, 1997: 51). This stipulated or "abjected" other figure is consequently separated from oneself. Through positioning it outside, the self feels safe in protecting the limits of its own identity without the threat of dissolving into otherness. The other is the stranger, the foreigner, the outsider and the one that is unlike us. All the authoritarian and fascist movements form a group of collective others and assign them to be the bearers of certain naturalistic traits that are considered to be different from one's own identity, and even a threat. Through such actions, this fear of losing ego boundaries and self-identity is manipulated (Benhabib, 1997: 52). Yet, for a certain group of us, it is necessary to confront the consequences of this instability. In the remarks of Iain Chambers, "It calls upon me to live in fluctuations between a displaced sense of Centre, or the ' $\mathrm{I}$ ', under the gaze of those other eyes/'I's, and to subscribe to a subsequent weakening and uncertainty within the limits of my thoughts and actions" (Chambers, 1994/2002: 19).

To put it another way, the inevitable relationship between the Self and the Other will only be meaningful to one as long as the other exists. As Bakhtin also notes, "I cannot manage without another, I cannot become myself without another; I must find myself in another by finding another in myself" (Bakhtin, 1999: 287). To summarize in this regard, as Spivak also remarks in his 1985 article "The Rani of Sirmur," the notion of the Other is based on a variety of philosophical and theoretical conceptions and the basis of "The Rani of Sirmur" is to concentrate on an understanding of ego that is a generalization of the Master-Slave dialectic developed in Hegel's Phänomenologie des Geistes"(Bakhtin, 1985: x). As mentioned earlier, Hegel explains the relationship between the other and self as a dialectical relationship between the soul's two parts: the master and the slave. Although this dialectic is overcome as the soul develops.

Another theoretical reference point will especially be Edward Said's conception of Orientalism. Joan Miller suggests that Said, who has faced a great deal of criticism in the context of social gender criticisms, fails to acknowledge women as active participants of imperialist power relations. Through an emphasis on the prominence of the female subject that weakens Said's description of masculine colonial subject, which is standardized and categorical to a large extent, Miller suggests that the positioning of women on different levels of societal gender degrees creates a less absolute point of view than what Said defines them to be (Ashcroft and Ahluwalia, 2001: 81). According to Lewis, Said in a way reemphasizes the importance of the notion of Otherness based on the criticism that by overlooking women, Said himself falls into the trap of stereotyping, which he believes to be the fundamental problem of Orientalism (Ashcroft and Ahluwalia, 2001: 81).

In light of the article "The Other Gender" by Simone de Beauvoir, considered as the pioneer of feminism and the existentialist struggle of women, it can be derived that the perception of Otherness is evaluated through gender issues and the view that men, as a norm, are perceived differently than women is predominating. The point that Beauvoir dwells upon is the distinction between the Self and the Other. While expressing this distinction through the relationship between the man and the woman, Beauvoir stresses that the essence is always threatened by Other. The presumptions on women should be abandoned and societal roles should be reconstructed in this sense (Coşkuner, 2015: 76). Right at this moment, as noted in Sune Qvotrup Jensen's Preliminary notes on othering and agency, Simone de Beauvoir's view that since the otherness of women also produces subjectivity, women are the way men shape them to be (Jensen, 2009, p.7), contains examples that can be encountered widely in the works of artists like Barbara Kruger (Image 1). 
Image 1: Barbara Kruger, Thinking of You, 1999 (Whitney, n.d.).

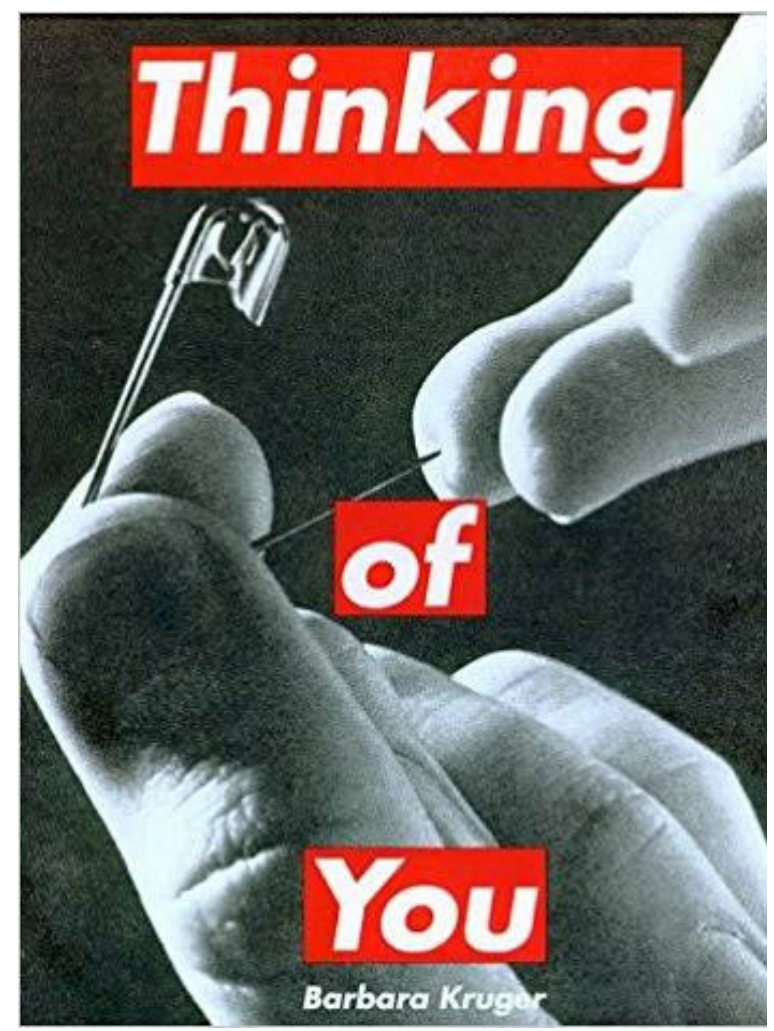

Kruger's workbased on mediatic consciousness situates itself at the intersection of mass communication, mass culture, and high art (Güner, 2013: 91). The works of the artist are widely characterized as facing the originality that points at the male hegemony and subverting these rigid and agitating modes of representation (Şahiner, 2008: 198-199). In this regard, Kruger sets her primary goal as destructing the popular culture's gender discriminatory attitude that is spread by the mass media tools. (Antmen, 2010: 279). Through using linguistic representations, such as Your/My or as seen in her other works I/You, to alter the subject, Kruger poses a criticism against the intellectual and social constructions under the male hegemony (Image 2) (Owens, 2001: 236). If Kruger's criticism is studied within the context of Otherness through the psychoanalyst Jacques Lacan's approaches, two significant discoveries add an additional layer to this study and to the notion of Otherness. First is that Language plays a central role in the production of identity; and the second is that in the formation of the Other, the agent of Identity is an inevitable factor. In the Lacanian thought, identities only exist as a symbolic part in the language's common subjectivity. This is to say that we in fact define ourselves through the meanings of language and in doing so, we bring ourselves to presence (Alsop, et al., 2002: 52). In line with this interpretation, Žižek distinguishes Lacan's approach in three forms of entities: the first is the Other Virtual or The big Other, second, on a symbolical level, is the "Symbolical Other," and the third other is the Evil Other (Vartanyan et al., 2008: 520).

The notion of objet petit $a$ or objet $a$, which Lacan has insisted on maintaining the original French term in translation to other languages, can be translated into English as the "object cause of desire." (The $a$ here is the first letter of the French word for autre, meaning Other). Object petit $a$ is not a real object; it is an object of desire, fantasy. In order to cope with this inexplicable and undefinable "excess" of the real that the symbolical system cannot contain within its limits, the subject creates an object of fantasy, starting from the first years of its existence as the Self. This object, the object of desire, does not actually exist; it is the fantasmatic equivalent of the primary deficiency that the subject does not know and can only glimpse at (Žižek, 2001: 307).

In other words, Lacans mirror stage lies at the centre of this discussion. During the self-development stage, the infants recognize their own reflections in the mirror. This recognition is on an illusory level until the age of six, and for the pathological self that is incapable of passing onto the symbolic level afterwards, anything that exists outside of the self is Other and stranger. Another definition for Other is a symbolic one, the interior Other, that the Self recognizes through the unconscious but cannot fully describe through the conscious. Desires, passions, ideals, god, governments, and laws are all embodied within this Other. The Other is not what stands on the opposite but what is leaned towards, an aggregate of the representation of symbolic order. The Other, acknowledging everything outside of itself, is the place for all desires. The name of the father - the government, god, the law-in short, is established upon anything that represents the symbolic order for the subject. Objet petit $a$, either female or male, is all tangible individuals outside of the self and what is missing in the subject-neighbours, friends, or enemies. And the Big Other represents a higher form of semantics-culture, society, groups, god, government, and laws (Tura, 1996: 131-147).

In terms of otherness that represents higher semantics, the place where consciousness takes a grip of itself is formed by a reflection that is foreign to the subject. Therefore, the ego becomes an identification through an imaginary reflection that is foreign to the subject. In 
this regard, the subject's gradual inclination towards the goal of capturing a state of self that is determined by the symbols of social order, or the Other, is due to the Other being foreign to the subject under the circumstances of this symbolic self, ratified by the Other itself.

The symbolic Other forms the society and this time, the differentiation is not according to $I$, but according to We. Once the individual sees oneself as a part of the society, the consciousness of Other begins to manifest itself. The Self has now dissolved into the Social Self. From this point on, the differentiations are not driven by the self but by the society that is being lived in. Jean Baudrillard explains this as the secret of the other: "It is never given to me to be myself, and that I exist only thanks to a fatal declination of something coming from elsewhere" (Baudrillard, 1995: 164).

"We have no will of our own, and the other is never what we would, of our own volition, choose to confront. Rather, the other is an invasion by something from elsewhere, priority given to what comes from elsewhere, seduction by foreignness and the transmission of foreignness" (Baudrillard, 1995: 164)

Image 2: Barbara Kruger, I shop therefore I am, 1987 (Acca, n.d.)

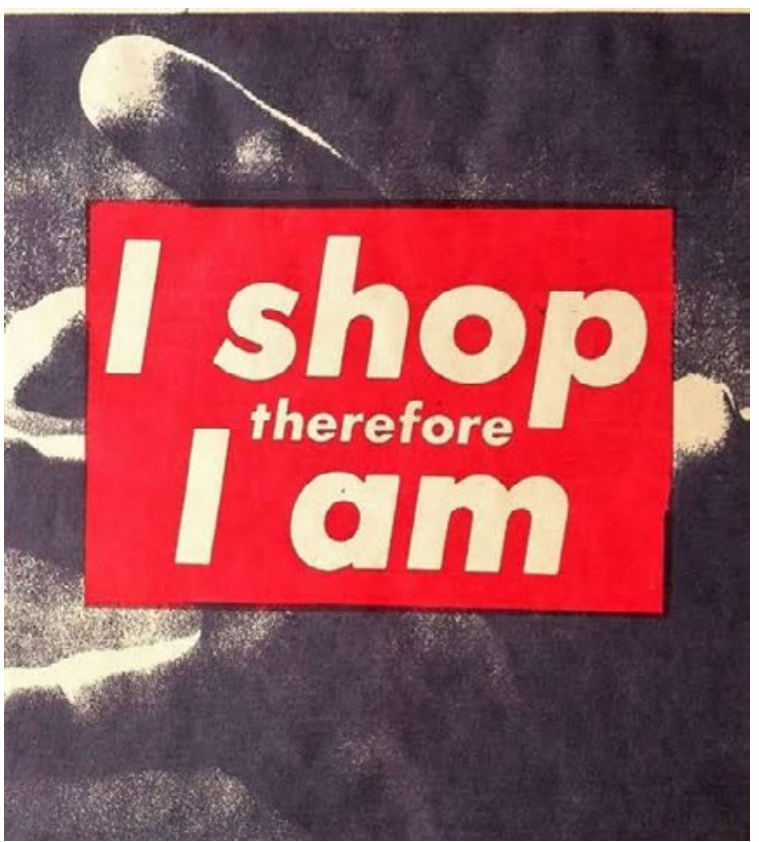

Consequently, as the notion of the Other is a reflection of a hierarchical relationship, it can be stressed that the consciousness of the Other can be considered as the result of different social behaviours caused by the cultural phenomenon. Gaining presence through the political expression of the Other, Orientalism has trapped the East within a conceptual framework and resurfaced its relationship with the Other in parallel with the perceptions around this conceptual framework. In Hegel's master-slave dialectic, the significance of the relationship constructed with Other, through the means of self-recognition and selfemancipation, has provided the opportunity to discuss the approaches of the abovementioned thinkers. Facing the Other and together with its differences and differences in general, the thought of getting to know these differences that constitute and fill our world is not merely about a geographical comparison. This also means to look out for a variety of different elements that occur within the bounds of our own culture.

In this section, the decisive institutionalism between the "I" and the "Other" as going from the "I" to "Us" and from the Other as a group, forms the subject and the object of the issue within itself. In this regard, in the process of going from I to Us, and from Other to Others as a group, the centre and periphery relationship has been investigated through the global art system, and is the central to the arguments in the next section of this study.

\section{CENTRE AND PERIPHERY RELATIONSHIP IN THE GLOBAL ART SYSTEM}

In this section, in the process leading to the Others, centre and periphery relationship will be examined through the global system. Within the framework of the notion of the Other, the focal point of this study will be the response to the question of under which perceptions of reality the paradigms that argue centre to be the centre or peripheries to remain out of the centre is assessed.

Different concepts of globalization find an interesting reflection in the works of contemporary artists. Some recognize the relationship between the centre and periphery to be primarily about the issues of hybridization and creolization, ${ }^{1}$ and by extension, blur the divisive line between the familiar and foreign, the owned and borrowed, near and far. Others, on the other hand, underscore the complexity of the contemporary relationship between the central and the local (Sztabińska, 2014: 46). According to this, the

'creole / creolization: The term creole in the English language, through the French créole meaning indigenous, has derived from the Portuguese word Criolulu (The Spanish criole) meaning native. Creole, by its unique use, refers to the European white (man) who was born and raised in the tropical colony (Spitzer, N. R. (2003) 
discussion of Contemporary Asian art, colonialism, and the positionalism maintained by the post-colonialist geopolitical conditions and economic realities of the global capitalism with a cultural dimension is to battle against the problem of the perception of a centre and a perimeter. In this regard, Lloyd states that, through the means of Biennales and Triennials in the AsianPacific region, a significant movement has been started to centralize the centre-perimeter model (Lloyd, 1997: 105). In his article "Reorienting: Japan Rediscovers Asia," Lloyd emphasizes that the Fukuoka Triennial, which has started especially in Japan in 1999, alongside Shanghai, New Delhi, Queensland, and Yokohama, has strayed from not only the East-West power structures and the centrality of places established like Venice, but also the Tokyo-centric Japanese art, as a result, initiated a double decentralization (Lloyd, 1997: 106). In addition, this pluralist and decentralized approach is defined as the tense and interlinked problems based on originality and identity that are covering Japan's other public sector politics, education, business.

Through her works about Japanese culture nationalism and Nihonjinronism ${ }^{2}$, the sociologist Yoshino Kosaku, who touches on these definitions, suggests that following the economic stillness in the 1990s and during the second phase of the bubble economy(!), main ideas regarding national culture has revived in Japan during this era of bubble economy (Kosaku, 1999: 23). In the cultural concept of the Nihonjinron, "race, ethnicity, and nation" are tightly connected within the theory of Japaneseness. Nihonjinron, which is based on "racial classifications and the state ideology of integration," is used to "not only mask ethnic minority issues in Japan, but also its intra-national, non-ethnic variations and conflicts." As a result, the primary goal is to preserve the "core of Japaneseness" (Eisenberg, 2009: 94).

In light of the preoccupation with the Japanese identity, which continues to be invigorated through various

\footnotetext{
${ }^{2}$ Nihonjinronism: Nihonjinron, also known as Nihon bunkaron, Nihon shakairon, Nihonron, etc., is a body of discourse which purports to demonstrate Japan's cultural differences from other cultures and Japan's cultural uniqueness in the world and thus tries to establish Japan's cultural identity. It is also said to be the world view of the middle class and the ideology of Everyman. Another proposition of Nihonjinron to date is a deliberate emphasis on how foreigners differ from Japanese. This hypothesis involves a particularistic way of looking at Japanese culture (as opposed to a universalistic way of thinking). In regards to the assimilation into the Japanese culture, mastering the Japanese language and achieving mutual understanding with Japanese, again, less than one half of the respondents thought foreigners lacked these cultural competencies. From these results, we can see how strong the particularistic way of thinking about Japanese culture is in the modern-day Japan.

For details, please refer to Kazufumi, M. and Befu, H. (1993). Japanese Cultural Identity. Japanstudien, 4(1), p. 89-102, DOI: 10.1080/09386491.1993.11827036, https: / / doi.org/10.1080/09386491.1993 .11827036
}

areas of life-graphic art, pop culture, and literature, to name a few-politicians are driven by the assumptions about core identity and the not so new concept of Nihonjinron in attacking the foreigners. In Eisenberg's view, although this concept of Nihonjinron has been ingrained in the Japanese society for centuries, it has only now managed to integrate itself in the political discourse of anti-immigration (Eisenberg, 2009: 94). In line with this, Yoshino firstly states that this antigovernmental rhetoric is produced and consumed only in the high culture market. While adding that beyond this, it simultaneously effects the daily behavioural culture, Yoshino further argues that in the general market, artists such as Takashi Murakami and Araki Nobuyoshi are attempting to actively spread. Kosaku supports that rather than representing ethnocentrism, Japanese culture nationalism is more of a form of ethnoperispherism as a result of the longstanding perception in Japan towards peripheral position of Japan and China in relation to the centralized civilizations (as cited in Weinsfeld, 2010: 23).

As noted by Appadurai also, the cultural resolutions of globalization take shape through discourses that affirm the process of modernity and are based on the oppositional view. Globalization, in this sense, is conceptualized in tandem with being concretized as a linear and homogenous process, resulting from the progression of Western modernity (Appadurai, 2002: 130). These conceptualizations that are constructed usually rest in the division between the centre and periphery and thus, the centre stretches from the West across the entire globe.

\section{BEING GLOBALIZED AND REPRESENTING THE OTHER IN ART}

As contemporary art is increasingly held equal to global art, art theorists and historians in search of the successor term to modernism and postmodernism, have suggested the network culture and globalization to be, among others, cultural conditions that are reflected by contemporary art. The critic and theorist Rex Butler suggests that the "new style or movement of art that comes after postmodernism," that is brought together by both the international circuit and effects of globalization on the concerns and content of contemporary art, should be called globalism (as cited in Potts, 2012). The greatest reason for this suggestion is that the works of art are in constant circulation due to the large art events they are exhibited in. If the case in which the suggested notion of Postmodernism evolves 
into Globalization is to be investigated, in order to stress the strict division between the before and after, referring to Zygmunt Bauman's comprehensive work Postmodernism and Displeasure would be, however indirect it may be, a meaningful approach due to its significance. Within this context, after evaluating what Postmodernity isn't through the notion of avantgarde, by touching upon the relationship between the Postmodern and Globalization, the modes in which the Other represents itself within this framework will be investigated.

After mentioning the literal meaning ${ }^{3}$ of avant-garde, Bauman talks about the distance which the avantgarde separates itself from the bulk on a temporal level: "What is being done at present by a small advance unit will repeated later by all." The assumption that lies beneath the perception of this guard as advanced is that "the rest will follow suit." Bauman underlines that in a world where we can speak of the avant-garde, the notions of forward and backward have at once spatial and temporal dimensions. Further stating that everything in the postmodern world is mobile, although this mobility is random, dispersed, and devoid of clear-cut direction, Bauman claims that "it is difficult, perhaps impossible" to judge their advance or retrograde nature. On one hand, the coordination between the spatial and temporal dimensions is completely destroyed; and on the other, space and time themselves repeatedly pronounce that they are devoid of an orderly and inherently differentiated structure (Bauman, 1997: 95). Thus, it is possible to associate the decentralization of hierarchies with the notion of Deleuze and Guattaris Rhizome. ${ }^{4}$

When the cultural conditions reflected by contemporary art, as well as the network culture and globalization, is considered, the multitude of styles and genres are not a projection of the time arrow on the spatial condition of cohabitation. Styles are no longer branched as

\footnotetext{
${ }^{3}$ The literal meaning of avant-garde is vanguard, an advance post, a spearhead or the first line of a moving army: a detachment which moves in front of the main body of the armed forces-but remains ahead only to pave the way for the rest of the army. Let's say, a platoon, which has captured a foothold in the territory still controlled by the enemy, will be followed by battalions, regiments, and divisions (Bauman, p. 95).

${ }^{4}$ Deleuze and Guattari explains this notion as such: "Rhizome is the antithesis if a root-tree structure, or arborescence. Arborescence are hierarchical...rhizomes, by contrast, are non-hierarchical, horizontal multiplicities." These unregulated and random rhizomes can only form a connection from a certain point with the rest of the points. Rhizomes contain segmented lines and may be ruptured or broken at certain spots. In Deleuze's view, rhizomes are not connected to a specif are not amenable to any structural or generative model. The rhizome can only intersect roots and sometimes merge with them. A rhizome has no beginning and an end; but most essentially, it has multiple entryways (Deleuze, G. and Guattari, F. (1974). Rhizome: introduction. Paris: Minuit).
}

progressive and retrograde, forward-looking and outdated. Today, new artistic inventions are not made to push out the ancient ones and replace them, but to join the Others through finding themselves a space in the infamously overcrowded setting of the art scene. This is a setting where diachrony is replaced with synchrony, succession with co-presence, and history with permanent present. All styles are subjected to the same laws that are applicable for all cultural creations produced for maximum effect and instant consumption (Bauman, 1997: 100). Bauman, stating that the postmodern art has almost no interest in the social reality, stresses that instead of this reality, they have elevated themselves to an unprecedented degree of reality that is self-sufficient. In this regard, to say that art as a whole, in the words of Jean Baudrillard, is in the postmodern culture not as culture of representation, but as a culture of simulacrum simply sums up the situation:

"...the importance of the work of art is measured today by publicity and notoriety (the bigger the audience, the greater the work of art). It is not the power of the image or carrying power of the voice that decide about the greatness of creation, but the efficiency of reproductive and copying machines...Andy Warhol made this situation an integral part of his own work... What counts, after all, is the number of copies sold, not what is being copied." (Bauman, 1997: 102)

On the behalf of the Other it is to emphasised that on the other hand, even though it is believed that the contemporary art, especially its avant-garde manifestations, rebels against the general dominant system, the truth that it gains a seductive commercial appeal within that system becomes prominent. Today, especially when the skilfulness of the artists, who have earned reputation through beginning to gain presence since the Reagan-Thatcher era, in the areas of marketing and image-making is considered, it can be underlined that the global capital directs the activities of art through strong and effective strategies. Naturally, even the most popular art institutions cannot escape this manipulation. Therefore, let alone challenging the system, an era where sponsorships are at the forefront is inevitable.

According to Şahiner, colonialism, making its presence felt on an economic and cultural level in the capitalist process, while invalidating and devaluating the knowledge of the Other, today, through assimilating the Other, turns into a knowledge that is sold in the global market as an ethic meta with the local products, 
traditions, and life practices. (Şahiner, 2015: 137). Multinational corporations, through awarding big prizes to artists with ethnic identities, almost confirm their position as being individuals who work with the media and styles of art approved by the dominant Western discourse of art. Those who are non-Western but have managed to get accepted by the Western mainstream art institutions are masters at egzoticizing themselves in pursuit of this goal. In his work Crisis of Representation in Contemporary Art Şahiner gives the example of the work one of the finalists of Hugo Boss (1988), Huan Yong Ping's Bugarach, to speak of the rise of many Japanese, Chinese, and Korean artists to the global stage as a result of being finalists for these prestigious awards (Şahiner, 2015: 137). An important point that Şahiner stresses is that the Fareast that blinds the West has a marketshare in this rise. In order to understand this side of the matter, the questions of how these organizations are structured and how these markets are set into motion by the global corporations provide substantially significant clues and datas.

\section{CONCLUSION}

The greatest impact of globalization is that it is multidimensional. This gives priority to the emergence of different parameters in the art world. Accordingly, it may be possible to arrive at two substantial conclusions. While the first is that together with globalization, the significance and area of use of knowledge has differentiated, the other is the role attributed to the Other. Knowledge determines the inevitable relationship between the Self and the Other. Acknowledging the notion of the Other as a reflection of a hierarchical relationship has demonstrated that the consciousness of the Other can be interpreted as the result of different social behaviours inflicted by the cultural phenomenon.

As for the emergence of different social behaviours in the present day, it is not only a result of conditions that determine the generation of social identity, the single status, religion, or the rural or urban origins. In the Postmodern era, in an attempt to tear down the difference between high and low culture, a dynamism in vertical structuring occurred as a result of the globalization of culture. Today, we are faced with a dynamism in horizontality that is being based on different cultural experiences. This situation reveals that art is shaping the conditions of the era within which one lives in-life practices and styles, perceptions, sensations, sensibilities, and modes of communication.
The questions and approaches concerning whether the age of globalization has ended or not and what possibly could happen afterwards put forth certain signs about globalization's evolution into a postglobalization, triggered by our day's events and novelties through a diversity of symptoms. Within these signs, undoubtedly, the global effect of the lavish and imperative nature of the geographical, ecological, political, and economical atmosphere of globalization's contemporary formation, to some extent, complicates the implementation of certain predictions and determinations regarding how the art world can be shaped.

\section{REFERENCES}

- (ACCA, N.D.). ICONS: Barbara Kruger, 'I shop therefore I am' Retrieved from https://acca.melbourne/program/iconsbarbara-kruger-i-shop-therefore-i-am/ (Accessed Date: 10/05/2020)

- ANTMEN, A. (2010). 20. Yüzyıl Batı Sanatında Akımlar. Istanbul Sel Yayıncilik.

- APAYDIN, E. (2006). Levinas Felsefesinde Öznelik ve Öteki Problemi (Master's thesis). Ankara University, Turkey.

- APPADURAI, A. (1990). Disjuncture and Difference in the Global Cultural Economy. Theory, Culture \& Society, 7(2), 130.

- ASHCROFT, B. \& AHLUWALIA, P. (2001). Edward Said. London UK: Routledge. (Original work published 1999).

- AYTEKIN, C. A. \& TOKDIL, E. (2016). Düşünce Sistemlerinde Ben ve Başkası Problemi, Arthur Rimbaud ve Sanatta Ötekilik Üzerine. Idil, 6(28), 17-30.

- BAKHTIN, M. (1999). Problem of Dostoevsky's Poetics. (C. Emerson, Ed. \& Trans.). (8th ed., pp. 376). Minneapolis, M: University of Minnesota Press. (Original work published 1984).

- BAUDRILLARD, J. (1995). The Transparency of Evil. (J. Benedict, Trans.). London, UK: Verso. (Original work published 1990).

- BAUMAN, Z. (1997). Postmodernity and Its Discontents. Cambridge, UK: Polity Press.

- BECK, U. (2002). The Cosmopolitan Society and it's Enemies. Theory, Culture and Society, 19(1-2), 36.

- BENHABIB, S. (1997). Strange Multiplicities: The Politics of Identity and Difference in a Global Context. Macalester International, 4

- JENSEN, S. Q. (2009). Preliminary notes on othering and agency: Marginalized young ethnic minority men negotiating identity in the terrain of otherness. (pp. 7). Aalborg: Aalborg Universitet.

- BUMIN, T. (1998). Hegel: Bilinç Problemi, Köle-Efendi Diyalektiği, Praksis Felsefesi. Istanbul: Yapı Kredi Yayınları.

- POTTS, J. (2012). Theorising Global Art. The Theme of Displacement in Contemporary Art. Retrieved from https:// erea.revues.org/2475\# tocto1n1

- CHAMBERS, I. (1994). Migrancy, Culture, Identity. London: Routledge.

- COŞKUNER, C. (2015). The Impacts of Jean Paul Sartre on Simone De Beauvoir. GSTF Journal of General Philosophy (JPhilo), 1(2), 76.

- DIKICI, E. (2014). Doğu-Batı Ayrımı Ekseninde Oryantalizm ve Emperyalizm. Tarih Kültür ve Sanat Araştırmaları Dergisi, 3(2). 
- EISENBERG, J. (2009). From Neo-Enlightenment to Nihonjinron: The Politics of Anti-Multiculturalism in Japan and the Netherlands. Macalester International, (22), 94. Retrieved from http: / / digitalcommons.macalester.edu/cgi/viewcontent. cgi? article $=1445 \&$ context $=$ macint 1

- FEYIZ, K. (2016). Diyalektiklerin Ötesi: Bataille, Foucalt ve Postmodern Transgresyon. Retrieved from http://www.karabatakdergisi.com/ deneme/dyalektklern-otes-batalle-foucalt-ve-postmode

- FOUCAULT, M. (2002). The Order of Things. London, UK: Routledge.

- GÜNER, B. (2013). Çağdaş Sanatta Müellif Sorunsalı. (The Problematic on Authorship in Contemporary Art) (pp. 91). Istanbul: FMV Işık University Graduate School of Social Sciences.

- HARDT, M. \& NEGRI, A. (2000). Empire. Cambridge, MA: Harvard University Press.

- HENRY, P. (2006). Africana Phenomenology: Its Philosophical Implications. Clr James Journal, 11(1), 79-112.

- KADER, C. (2015). Emmanuel Levinas Felsefesinde "Başkalık ve Aynılık" Problemi. Mütefekkir, 2(3), 77-91.

- KAZUFUMI, M. and Befu, H. (1993). Japanese Cultural Identity. Japanstudien, 4(1), p. 89-102, DOI: 10.1080/09386491.1993.11827036.

- NAHYA, N. Z. (2011). İmgeler ve Ötekileştirme: Cadılar, Yerliler, Avrupalılar. Atılım Sosyal Bilimler Dergisi, 1(1), 29.

- OWENS, C. (2001). Art and Feminism. (H. Reckitt, \& P. Phelan Eds.). Hong Kong: Phadion Press Ltd.

- ALSOP, R. \& FITZSIMONS R., A. and Lennon, K. (2002). Theorizing Gender: An Introduction. Wiley, 51. ISBN: 978-0-7456-1944-6

- SOFUOĞLU, H. (1996). Ötekilik Melodramı. Retrieved from https:/ / earsiv.anadolu.edu.tr/xmlui/bitstream/ handle $/ 11421 / 1020 / 113614$.pdf? sequence $=2 \&$ is Allowed $=y$

- SZTABIŃSKA, P. (2014). Contemporary Artist and The Notion Of Centre And Periphery, Art Inquiry. Recherches Sur Les Arts, (XVI), 48.

- ŞAHINER, R. (2015). Çăgdaş Sanatta Temsiliyet Krizi. Ankara: Ütopya Yayınevi, Sanat Dizisi.

- ŞAHINER, R. (2008). Sanatta Postmodern Kirllmalar ya da Modernin Yapibozumu. Istanbul: Yeni İnsan Yayınevi.

- SPITZER, N.R. (2003). Monde Créole: The Cultural World of French Louisiana Creoles and the Creolization of World Cultures. Journal of American Folklore, 116(459), 57-72.

- TÜRK, D. (2013). Öteki, Düşman, Olay-Levinas, Schmitt ve Badiou'da Etik ve Siyaset. Istanbul: Metis Yayınları.

- TURA, S. M. (1996) Freud'dan Lacan'a Psikanaliz. Istanbul: Ayrıntı Yayınları

- ULUÇ, G.\& MIKAIL BOZ, M. (2015). Karşılıklı Ötekileştirmeye bir yolculuk: "Otobüs" Filmi. Turkish Journal of Tesam Academy, 110.

- VARTANYAN, A., ÖZTÜRKMEN, A., MARGOSYAN, A. \& KECHRIOTIS, V. (2008). Aynı Toprakta Öteki Olmak, "Ĕger sürekli dostluktan bahsetme ihtiyacı hissediyorsaniz, bu ortada öyle bir dostluk olmadığı anlamına gelir." Mithat Alam Film Merkezi Söyleşi, Panel ve Sunum Yıllığı, 520. Retrieved from http://www.mafm.boun. edu.tr/files/110_Panel1.pdf

- WEISENFELD, G. (2010). Reinscribing Tradition in a Transnational Art World, Duke University.

- WILSON LLOYD, A. (1999). Reorienting: Japan Rediscovers Asia. Art in America, 87(10), 105.

- ŽIŽEK, S. (2000). The Fragile Absolute. London, UK: Verso. 